\title{
Pandemi Covid-19 Dalam Penyajian Pelaporan Keuangan dan Keberlangsungan Usaha Melalui Prediksi Kebangkrutan
}

\section{Shinta Budi Astuti, Ameilia Damayanti, Tryas Chasbiandani, dan Nelyumna Rizal}

Fakultas Ekonomi dan Bisnis Universitas Pancasila Jakarta

J1. Raya Lenteng Agung No. 58-80 Jakarta, 12640, Indonesia

\section{Info Artikel}

Keywords:

Business Continue; Bankruptcy;

Altman Z-Score.

Kata Kunci:

Going Concern, Kebangkrutan,

Covid-19, Altman Z-Score

ISSN (print): 2598-7763

ISSN (online): 2598-7771

$\triangle$ Corresponding Author:

Shinta Budi Astuti:

Tel. /Fax.

E-mail:

shintabudi-

astuti@univpancasila.ac.id

\begin{abstract}
Abtract
The main purpose of this study is to assess and analyze the business continuity (going concern) of companies before and during the Covid-19 pandemic. The sample of this research is 45 property sector companies listed on the Indonesia Stock Exchange (BEI) for the period 2019-2020 and meet predetermined criteria. This study uses the Altman Z-Score bankruptcy prediction model to assess the business continuity of the sample companies. This research proves that there is indeed an influence from the global Covid-19 pandemic. Companies that are experiencing financial problems and have a strong potential for bankruptcy increased from 2\% at the end of 2019 to $51 \%$ at the end of June 2020.
\end{abstract}

Citation: Astuti, S.B., Damayanti, A., Chasbiandani, T, dan Rizal, N. (2020). PandemiCovid-19 dalam Penyajian Pelaporan Keuangan dan Keberlangsungan Usaha Melalui Prediksi Kebangkrutan. AFRE Accounting and Financial Review. 3(2): 164-170

\begin{abstract}
Abstraks
Tujuan utama penelitian ini adalah untuk menilai dan menganalisa keberlangsungan usaha (going concern) perusahaan-perusahaan sebelum dan pada saat pandemi Covid19. Sampel penelitian ini adalah 43 perusahaan sektor properti yang terdaftar di Bursa Efek Indonesia (BEI) periode 2019-2020 dan memenuhi kriteria-kriteria yang telah ditentukan. Penelitian ini menggunakan prediksi kebangkrutan model Altman Z-Score untuk menilai keberlangsungan usaha perusahaan yang dijadikan sampel. Penelitian ini membuktikan bahwa memang terdapat pengaruh dari pandemic global Covid-19. Perusahaan yang mengalami permasalahan keuangan dan memiliki potensi kuat mengalami kebangkrutan bertambah dari 2\% diakhir tahun 2019 menjadi 51\% pada akhir Juni 2020.
\end{abstract}

JEL Classification: C31, E50

DOI: https://doi.org/10.26905/afr.v3i2.5451

\section{PENDAHULUAN}

WHO telah mengumumkan virus COVID19 menjadi pandemi pada 11 Maret 2020, yang kemudian tanggal 14 Maret ditetapkan sebagai bencana nasional non alam oleh pemerintah Republik Indonesia. Pada saat itu mulai dilakukan pembatasan-pembatasan, yang dimulai dari anjuran Presiden Jokowidodo untuk bekerja, belajar dan beribadah di rumah. Pembatasan-pembatasan kegiatan ekonomi pun terjadi. Toko-toko, pusat pembelanjaan banyak ditutup, begitu juga dengan pabrik-pa-brik. Semua pembatasan tersebut tentunya berdampak pada perputaran keuangan perusahaan yang bisa jadi nantinya akan berimbas pada keberlangsungan usaha perusahaan (going concern). 
Pandemi akibat Covid-19 telah berdampak pada keberlangsungan perusahaan. Banyak perusahaan mengalami kesulitan keuangan (Wang et al., 2020). Perekonomian hampir semua semua negara di dunia kena dampak Pandemi Covid-19, aktivitas perekonomian mengalami kesulitan. Arus kas perusahaan bermasalah, akibat penjualan yang anjlok. Kondisi ini dapat memicu terjadinya kebangkrutan, efisiensi perusahaan anjlok (Didier et al., 2020; Usheva \& Vagner, 2020 dan Iverson et al., 2020, Skvortsova et al., 2020; dan Hunter \& Shannon, 2020; Altig et al., 2020).

Informasi tentang operasional, pencapaian dan posisi keuangan perusahaan sebenarnya bisa dilihat dari laporan keuangan. Selama ini para investor atau stakeholders lainnya menjadikan laporan keuangan yang sudah diaudit sebagai salah satu sumber untuk mengambil keputusan (Nguyen et al., 2016; Blessing \& Onoja, 2015; Amedu, 2008; Alkaraan \& Northcott, 2007; (Hodge \& Pronk, 2006; dan Go'mez-Guillamo'n, 2003) Tetapi bila dilihat dari situasi sekarang apakah laporan keuangan perusahaan 2019 sudah menangkap situasi saat ini dimana adanya pembatasanpembatasan ekonomi yang terjadi, apakah angkaangka yang disajikan pada laporan keuangan bisa dipakai untuk membuat prediksi dan perencanaan, dan yang terpenting bagaimana mengukur keberlangsungan entitas-entitas tersebut (Prayoga et al., 2021; Wulandari \& Maslichah, 2021; dan Zakariya et al., 2020).

Pada 1 April 2020 IAI mengeluarkan press release yang menyatakan bahwa Covid-19 tidak bisa dijadikan dasar peristiwa yang mengharuskan entitas bisnis melakukan penyesuaian atas Laporan Keuangan 2019. Mengingat, penyebaran Covid-19 di Indonesia baru diumumkan terjadi pada tanggal 2 Maret 2020 dan bukan informasi yang dapat mempengaruhi penyajian laporan keuangan 2019.

Kompleksitas terkait dengan akuntabilitas dan tata keloa perusahaan telah meningkat akibat pandemi Covid-19. Penyajian laporan keuangan pada masa pandemi menjadi menarik, ketika ada permasalahan yang mempengaruhi semua aktivitas ekonomi (Ozili, 2021); (Shen et al., 2020); (Rinaldi et al., 2020).

Berdasarkan hal tersebut, studi kali ini akan menilai dan menganalisa keberlangsungan usaha (going concern) pada masa pendemi Covid-19. Penelitian ini bertujuan untuk menilai dan menganalisa keberlangsungan usaha (going concern) perusahaan-perusahaan sebelum dan pada saat pandemi Covid-19.

\section{LITERATUR REVIEU}

Keberlangsungan usah merupakan hal penting bagi stakeholders terutama bagi investor. Oleh sebab itu keberlangsungan usaha dipandang juga sebagai proporsi dari keamanan moneter yang dimiliki perusahaan yang erat kaitannya dengan kemampuan manajemen dalam mengelola perusahaan agar dapat terus berjalan.

Beberapa peristiwa yang mungkin bisa mengancam keberlangsungan usaha perusahaan diantaranya (Husnan, 2014): a) Tren negatif, sebagai contoh, kerugian operasi yang berulang terjadi, kekurangan modal kerja, arus kas negatif dari kegiatan usaha, rasio keuangan penting yang buruk. b) Petunjuk lain tentang kemungkinan kesulitan keuangan, sebagai contoh, kegagalan dalam memenuhi kewajiban utang atau perjanjian serupa, penunggakan pembayaran deviden, penolakan oleh pemasok terhadap pengajuan permintaan pembelian kredit biasa, restrukturisasi utang, kebutuhan untuk mencari sumber atau metode pendanaan baru, atau penjualan sebagian besar aktiva. c) Masalah intern, sebagai contoh, pemogokan kerja atau kesulitan hubungan perburuhan yang lain, ketergantungan besar atas sukses proyek tertentu, komitmen jangka panjang yang tidak bersifat ekonomis, kebutuhan untuk secara signifikan memperbaiki operasi. d) Masalah luar yang telah terjadi, sebagai contoh, pengaduan gugatan pengadilan, keluarnya undang-undang atau masalah-masalah lain yang kemungkinan membahayakan kemampuan entitas untuk beroperasi, kehilangan franchise, lisensi atau paten penting, kehilangan pelanggan atau pemasok utama, kerugian akibat bencana besar.

Faktor internal yang bisa menyebabkan kebangkrutan perusahaan meliputi manajemen yang tidak efisien, jadi manajemen yang tidak efisien akan mengakibatkan kerugian terus-menerus yang pada akhirnya menyebabkan perusahaan tidak mampu membayar kewajibannya (Putri et al., 2018, Fauzia, 2017; dan Darsono dan Ashari (2010:12). Ketidakefisienan ini diakibatkan oleh pemborosan dalam biaya, kurangnya keterampilan dan keahlian manajemen. Kemudian ketidakseimbangan modal dengan jumlah utang-piutang. Utang yang terlalu besar akan mengakibatkan biaya bunga yang besar sehingga memperkecil laba bahkan bisa mengakibatkan kerugian. Piutang yang terlalu besar juga akan merugikan karena aktiva yang menganggur terlalu banyak sehingga tidak menghasilkan pendapatan. Yang terakhir yaitu Moral hazard oleh manaje- 
men. Kecurangan yang dilakukan oleh manajemen perusahaan bisa mengakibatkan kebangkrutan. Kecurangan berbentuk manajemen yang korupsi ataupun memberikan informasi yang salah pada pemegang saham atau investor.

Faktor eksternal yang bisa mengakibatkan kebangkrutan adalah: a) Perubahan dalam keinginan pelanggan yang tidak diantisipasi oleh perusahaan yang mengakibatkan pelanggan lari sehingga terjadi penurunan dalam pendapatan. $b$ ) Kesulitan bahan baku karena supplier tidak dapat memasok lagi kebutuhan bahan baku yang digunakan untuk produksi. c) Terlalu banyak piutang yang diberikan kepada debitur dalam jangka waktu pengembalian yang lama akan mengakibatkan banyak aktiva yang menganggur yang tidak memberikan penghasilan sehingga mengakibatkan kerugian yang besar bagi perusahaan. d) Hubungan yang tidak harmonis dengan kreditur juga bisa berakibat fatal terhadap kelangsungan hidup perusahaan. e) Persaingan bisnis yang semakin ketat menuntut perusahaan agar selalu memperbaiki diri sehingga bisa bersaing dengan perusahaan lain dalam memenuhi kebutuhan pelanggan. f) Kondisi perekonomian secara global juga harus selalu diantisipasi oleh perusahaan.

Ada beberapa indikator untuk melihat tanda-tanda kesulitan keuangan dapat diamati dari pihak eksternal, misalnya: a) Penurunan jumlah deviden yang dibagikan kepada pemegang saham selama beberapa periode berturut-turut. b) Penurunan laba secara terus-menerus bahkan perusahaan mengalami kerugian. c) Ditutup atau dijualnya satu atau lebih unit usaha. d) Pemecatan pegawai secara besar-besaran. e) Harga di pasar mulai menurun terus-menerus.

Altman Z Score adalah skor yang ditentukan dari rasio-rasio keuangan dimana rasio tersebut mendeteksi kondisi keuangan perusahaan yang berkaitan dengan likuiditas, profitabilitas dan aktivitas perusahaan. Terdapat lima rasio yang dikombinasikan oleh Altman untuk menghitung Z-Score (Susilowati \& Simangunsong, 2019; Puspita, 2019; Ananda, 2018; dan Shahwan, 2015) yaitu: a) Working Capital to Total Assets, merupakan salah satu rasio likuiditas yang mengukur ketersediaan modal kerja bersih dari total aset perusahaan dalam rangka mendukung operasional perusahaan. b) Retained Earnings to Total Assets, merupakan rasio yang mengukur akumulasi laba selama perusahaan berjalan. Rasio ini juga merupakan rasio untuk mengukur kemampuan perusahaan untuk menghasilkan laba di-tahan dari total aktiva perusahaan. c) EBIT to Total
Assets, merupakan rasio untuk mengukur besarnya keuntungan yang dihasilkan perusahaan dari operasional total aset yang dimiliki perusahaan, d) Book Value Equity to Book Value of Total Debt, untuk mengukur seberapa besar dampak hutang terhadap penurunan nilai aset perusahaan. e) Sales to Total Assets, untuk mengukur kemampuan total aset yang dimiliki perusahaan dalam menghasilkan penjualan.

\section{DATA DAN METODE}

Penelitian ini merupakan penelitian kuantitatif yang bertujuan mengukur keberlangsungan hidup perusahaan melalui metode kebangkrutan Altman Z Score. Jenis data yang digunakan adalah data kuantitatif dengan menggunakan data sekunder. Data sekunder merupakan data yang diperoleh peneliti secara tidak langsung. Sampel penelitian merupakan perusahaan yang bergerak dibidang properti. Pendekatan penelitian ini menggunakan pendekatan deskriptif. Pendekatan deskriptif hanya mengumpulkan, menyusun, mengklasifikasikan dan menafsirkan data dngan melakukan perbandingan antara teori-teori dengan data yang terjadi sehingga memberikan gambaran yang lengkap tentang permasalahan penelitian. Teknik analisis data meng-gunakan teknik analisis deskriptif. Model prediksi kebangkrutan Altman Z-Score dihitung dengan:

$Z$-Score $=1,2 X_{1}+1,4 X_{2}+3,3 X_{3}+0,6 X_{4}+0,999 X_{5}$,

Dimana: $\mathrm{X}_{1}=$ Working Capital to Total Assets; $\mathrm{X}_{2}=$ Retained Earnings to Total Assets; $X_{3}=$ EBIT to Total Assets; $X_{4}=$ Book Value Equity to Book Value of Total Debt dan $X_{5}=$ Sales to Total Assets

Penggolongan nilai Z-Score berdasarkan penafsiran dari nilai $Z$ dengan kecendeungan kondisi perusahaan disajikan pada tabel 1. Pada table 1, menunjukkan bagaimana kondisi prediksi perusahaan dengan nilai perhitungan Z-Score suatu perusahaan. Semakin rendah nilai Z-Score kecendrungan atau poteni perusahaan akan mengalami kebangkrutan akan semakin tinggi.

Tabel 1. Klasifikasi Nilia Z-Score

\begin{tabular}{ll}
\hline Nilai Z-Score & Keterangan \\
\hline Z-Score $>2,99$ & Perusahaan dianggap aman \\
$2,70 \leq$ Z-Score & Keuangan di suatu bagian yang \\
$<2,99$ & membutuhkan perhatian khusus \\
$0,80 \leq$ Z-Score $<$ & Ada kemungkinan perusahaan \\
2,70 & akan mengalami kebangkrutan \\
& dalam 2 tahun ke depan \\
$Z<1,80$ & $\begin{array}{l}\text { Perusahaan berpotensi kuat akan } \\
\text { mengalami kebangkrutan }\end{array}$ \\
\hline
\end{tabular}


Berdasarkan nilai Z-Score akan diinter-prestasikan secara kualitatif untuk menjelaskan kondisi industri properti dalam situasi sebelum dan ketika terjadinya pandemi global Covid-19. Perusahaan dengan nilai Z-score tertentu apakah dalam klasifikasi aman, membutuhkan perhatian khusus, berpotensi rawan bangkrut dalam dua (2) tahun ke depan, atau berpotensi kuat akan mengalami kebangkrutan.

\section{HASIL}

Dalam penelitian ini variabel yang digunakan adalah Working Capital to Total Assets, Retained Earnings to Total Assets, EBIT to Total Assets, Book Value of Equity to Book Value of Total Debt, Sales to Total Assets. Sampel penelitian yang digunakan adalah perusahaan properti yang terdaftar di Bursa Efek Indonesia (BEI) sejak awal tahun 2019, telah mengeluarkan laporan keuangan pada Desember 2019 dan Juni 2020, serta lengkap menyajikan data yang dibutuhkan dalam penelitian ini. Dari ketiga kriteria tersebut jumlah sampel yang diperoleh sebanyak 43 perusahaan.

Tabel 1. Statistik Deskriptif

\begin{tabular}{lrrrr}
\hline & \multicolumn{2}{c}{ Jun-20 } & \multicolumn{2}{c}{ Des-19 } \\
Var & Rerata & St. Dev & \multicolumn{1}{c}{ Rerata } & \multicolumn{1}{c}{ St. Dev } \\
\hline $\mathrm{X}_{1}$ & 0,234 & 0,210 & 499,494 & 3174,027 \\
$\mathrm{X}_{2}$ & 0,267 & 0,262 & 0,329 & 0,501 \\
$\mathrm{X}_{3}$ & 0,000 & 0,023 & 0,044 & 0,086 \\
$\mathrm{X}_{4}$ & 2,724 & 3,410 & 24,889 & 15,186 \\
$\mathrm{X}_{5}$ & 0,114 & 0,146 & 25,238 & 15,186 \\
\hline
\end{tabular}

Tabel 2 menampilkan hasil statistik deskriptif untuk rasio-rasio yang digunakan pada model Altman Z-Score. Hasil analisis statistik deskriptif dapat disimpulkan bahwa nilai rata-rata $X_{1}$ pada perusahaan properti pada tahun 2019 sebesar 499,493 dengan standar deviasi sebesar 3174,027. Hal ini menunjukan bahwa data $X_{1}$ memiliki sebaran yang besar dan bervariasi karena standar deviasi lebih besar dari nilai rataratanya. Sebaran yang besar dan bervariasi ditunjukan juga pada data $\mathrm{X}_{2}, \mathrm{X}_{3}$. Sedangkan pada data $X_{4}$ dan $X_{5}$ nilai rata-rata lebih besar dibandingkan dengan standard deviasi yang menunjukan sebaran kedua data tersebut tidak begitu besar dan tidak bervariasi. Hasil analisis statistik deskriptif berdasarkan laporan keuangan semester pertama 2020, menunjukan bahwa keadaan data $X_{4}$ berbeda dengan tahun 2019. Data $X_{4}$ menunjukan standar devisi lebih besar dibandingkan nilai rata-ratanya. Hal tersebut menunjukan seba- ran datanya cukup besar dan bervariasi. Berdasarkan hasil perhitungan nilai Z-Score 43 perusahaan dengan menggunakan data Desember 2019 dan Juni 2020 disajikan pada tabel 3.

\begin{tabular}{lll} 
Tabel. 3 Nilai Z-Score & & \\
\hline & $\begin{array}{l}\text { Jumlah } \\
\text { Perusahaan } \\
\text { (Juni 2020) }\end{array}$ & $\begin{array}{l}\text { Jumlah } \\
\text { Perusahaan } \\
\text { (Desember } \\
\text { 2019) }\end{array}$ \\
Nilai Z-score & 9 & 40 \\
\hline Z-Score $\geq 2,99$ & 0 & 0 \\
$2,70 \leq$ Z-score $>2,99$ & 12 & 1 \\
$1,8 \leq$ Z-score $>2,70$ & 22 & 2 \\
Z-score $<1,8$ & 43 & 43 \\
Jumlah & & \\
\hline
\end{tabular}

\section{PEMBAHASAN}

Berdasarkan hasil analisis nilai Z-Score menunjukkan bahwa, 40 Perusahaan properti dalam sampel ini, selama Desember tahun 2019, berada dalam kondisi aman, sedangkan 1 perusahaan menghadapi potensi kebangkrutan di 2 tahun kedepan dan 1 perusahaan berpotensi kuat akan mengalami kebangkrutan. Pademi covid-19 yang kemudian terjadi di Indonesia, diawali pada tanggal 11 Maret 2020 pemerintah mengumumkan kasus pertama yang terjadi di Indonesia dan kemudian ditetapkan sebagai bencana nasional non alam oleh pemerintah RI di tanggal 14 Maret 2020, memberikan dampak yang signifikan terhadap perusahaan properti di Indonesia. Dilihat dalam tabel 3, terdapat angka yang cukup signifikan untuk perusahaan dengan nilai Z-score kurang dari 1,8, dimana pada Juni 2020, terdapat 22 perusahaan yang memiliki nilai Z-score dibawah 1,8 atau bertambah 20 perusahaan memiliki potensi yang kuat akan menghadapi kebangkrutan. Hal lain yang sejalan yaitu kenaikan jumlah perusahaan dengan nilai Z-score lebih dari 1,8 namun kurang dari 2,70 pada Juni 2020, yaitu sebanyak 12 perusahaan, yang berarti perusahaan tersebut menghadapi potensi kebangkrutan di 2 tahun yang akan datang. Hanya 9 perusahaan berada dalam kondisi aman di bulan Juni 2020.

Berdaarkan gambar 1, dapat dilihat bahwa pada Desember 2019, sebelum terjadi pandemi Covid-19, hanya $2 \%$ perusahaan pada sektor properti yang memiliki Z-score dibawah 1,8 yang berarti bahwa perusahaan mengalami perma-salahan keuangan dan memiliki potensi kuat mengalami kebangkrutan. $5 \%$ pada perusahaan properti memiliki nilai Z-score lebih besar dari 1,8 namun kurang dari 2,7 yang artinya perusahaan tersebut berada di area abu-abu. Berpotensi me- 
ngalami kebangkrutan dalam 2 tahun yang a-kan datang jika tidak dilakkan perbaikan atau restrukturisasi keuangan. Sedangkan sisanya sebanyak 93\% perusahaan properti di Indonesia ber-ada dalam kondisi keuangan yang sehat, karena memiliki nilai Z-score lebih dari 2,99. Menun-jukkan betapa berkembangnya perusahaan pro-perti di Indonesia dan perekonomian Indonesia yang semakin baik karena masyarakat mampu berkontribusi dalam perekonomian di bidang properti.

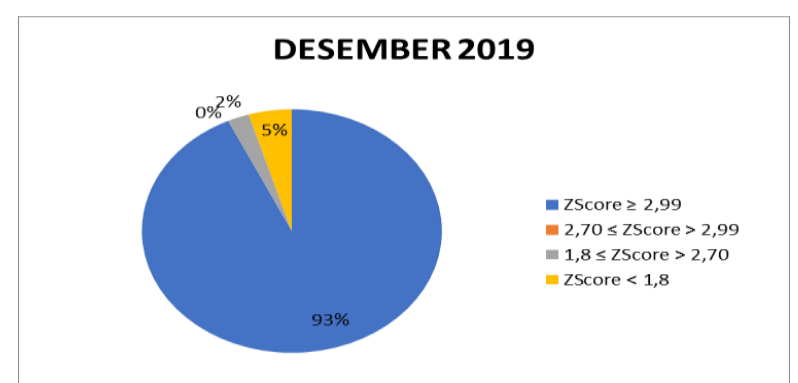

Gambar 1 Diagram Nilai Z-Score perusahaan properti Desember 2019

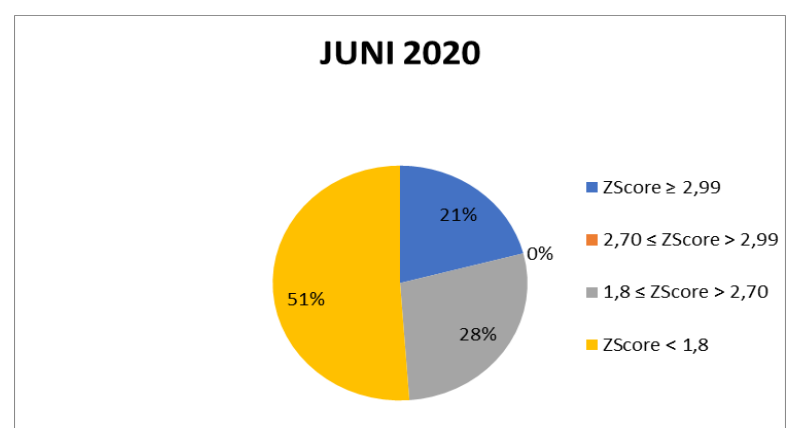

Gambar 2 Diagram Nilai Z-Score perusahaan properti Juni 2020

Hal yang esktrim terjadi pada Juni 2020, dimana pandemi Covid 19 sudah terjadi dan perusahaan properti mulai mengalami permasalahan dalam hal keuangan (Gambar 2). Terlihat dari grafik bahwa sebanyak $51 \%$ perusahaan di bidang pro-perti memperoleh nilai Z-score dibawah 1,8 yang artinya perusahaan memiliki potensi kebang-krutan. $28 \%$ perusahaan properti pada bulan Juni 2020 berada di zona abu-abu dengan nilai Zscore lebih besar dari 1,8 namun kurang dari 2,70. Per-usahaan mengalami risiko kebangkrutan 2 tahun yang akan datang. Sisanya sebanyak 21\% masih dalam posisi aman. Perusahaan properti di Indonesia masih mampu bertahan di masa pandemi Covid 19 sebanyak 21\%.

\section{SIMPULAN DAN SARAN}

Berdasarkan hasil analisis dan pembahasan dapat diambil kesimpulan bahwa hasil dari perhitungan Z-Score tersebut menunjukan bahwa sektor properti cukup terpengaruh dengan situasi pandemi global Covid-19. Banyak perusahaan yang terguncang dan mengalami kesulitan dalam masa pendemi covid-19, lalu perusahaan yang berpotensi mengalami kebangkrutan dalam 2 tahun yang akan datang jika tidak dilakukan perbaikan atau resktrukturisasi keuangan sekitar $28 \%$, kemudian perusahaan berpotensi kuat akan mengalami kebangkrutan sekitar 51\%, dan sebanyak sekitar $21 \%$ perusahaan dalam kondisi aman dari kebangkrutan.

Kondisi pandemi global Covid-19 ini adalah hal yang belum pernah dialami oleh dunia industri modern. Saat ini dunia dalam ketidakpastian, masyarakat lebih banyak untuk menunda melakukan investasi dan konsumsi diluar hal primer. Untuk melihat kondisi keberlangsungan industri properti bila dimungkinkan mencari alternatif pengukuran selain metode Altman Z-Score yang bisa memasukan kondisi pandemi global ini. Selain itu masih perlu dilakukan observasi atas sektor ini setelah kebijakan PSBB (Pembatasan Sosial Berskala Besar) di Indonesia mulai dilonggarkan.

\section{DAFTAR PUSTAKA}

Alkaraan, F., \& Northcott, D. (2007). Strategic investment decision making: The influence of pre-decision control mechanisms. Qualitative Research in Accounting $\mathcal{E}$ Management, 4(2), 133-150. https://doi.org/10.1108/11766090710754204

Altig, D., Baker, S. R., Davis, S. J., Meyer, B. H., Parker, N. B., Thwaites, G., Altig, D., Baker, S. R., Barrero, J. M., Bloom, N., Bunn, P., Chen, S., Davis, S. J., Leather, J., Meyer, B. H., Mihaylov, E., Mizen, P., Parker, N. B., Renault, T., ... Parker, N. B. (2020). Economic Uncertainty Before and During the COVID-19 Pandemic.

Amedu, A. M. (2008). Role Financial Statement in Investment Decision Making (A Case Study of First Bank nof Nigerian PLC). 32.

Blessing, A., \& Onoja, E. E. (2015). The role of financial statements on investment decision making: a case of united bank for africa plc (2004-2013). European Journal of Business, Economics and Accountancy, 3(2), 12-37.

Didier, T., Huneeus, F., Larrain, M., \& Schmukler, S. L. (2020). Financing firms in hibernation during the COVID-19 pandemic. Research $\mathcal{E}$ 
Policy Briefs From the World Bank Chile Center and Malaysia Hub, 30. https://doi.org/10.1016/j.jfs.2020.100837

Fauzia, I. Y. (2017). Mendeteksi Kebangkrutan Secara Dini Perspektif Ekonomi Islam. EKUITAS (Jurnal Ekonomi Dan Keuangan), 19(1),

90. https://doi.org/10.24034/j25485024.y2015.v 19.i1.1758

Go'mez-Guillamo'n, A. D. (2003). The usefulness of the audit report in investment and financing decisions. In Managerial Auditing Journal (Vol. 18, Issue May). https://doi.org/10.1108/02686900310482623

Hodge, F., \& Pronk, M. (2006). The impact of expertise and investment familiarity on investors' use of online financial report information. Journal of Accounting, Auditing and Finance, 21(3), 267-292. https://doi.org/10.1177/0148558X06021003 04

Hunter, R. J., \& Shannon, J. H. (2020). Managing Financial Stress for Debtors and Creditors in the Midst of a Pandemic Part II: Bankruptcy. International Journal of Business Management and Commerce, 5(3).

Iverson, B., Ellias, J. A., \& Roe, M. (2020). Estimating The Need for Additional BAnkruptcy Judges in Light of The Covid-19 Pandemic. Harvard Business Law Review, 11.

Nguyen, L. T. M., Gallery, G., \& Newton, C. (2016). The influence of financial risk tolerance on investment decision-making in a financial advice context1. Australasian Accounting, Business and Finance Journal, 10(3), 3-22. https://doi.org/10.14453/aabfj.v10i3.2

Ozili, P. K. (2021). Accounting and Financial Reporting During a Pandemic. New Challenges for Future Sustainability and Wellbeing, 105183, 87-93. https://doi.org/10.1108/978-1-80043-968920211005

Prayoga, Y., Siregar, M., Sari, E. R., \& Rambe, B. H. (2021). Penggunaan Informasi Akuntansi Pada Industri Usaha Kecil Dan Menengah Pada Masa Pandemi Covid - 19. Ecobisma (Jurnal Ekonomi, Bisnis Dan Manajemen), 8(1), 1-9. https://doi.org/10.36987/ecobi.v8i1.2027

Puspita, M. P. P. G. (2019). Tingkat Laba dan Perubahan Laba: Manakah yang Lebih Relevan? AFRE (Accounting and Financial Review), 2(2), 91-97. https://doi.org/10.26905/afr.v2i2.3091

Putri, E. L., Haryanto, S., \& Firdaus, R. M. (2018). Mampukah Good Corporate Governance dan Risiko Kredit Sebagai Prediktor Financial Distress? AFRE (Accounting and Financial Review), 1(1). https://doi.org/10.26905/afr.v1i1.2291

Rinaldi, L., Cho, C. H., Lodhia, S. K., Michelon, G., \& Tilt, C. A. (2020). Accounting in times of the COVID-19 pandemic: a forum for academic research. Accounting Forum, 44(3), 180-183.

https://doi.org/10.1080/01559982.2020.1778 873

Shahwan, T. M. (2015). The effects of corporate governance on financial performance and financial distress: evidence from Egypt. Corporate Governance (Bingley), 15(5), 641-662. https://doi.org/10.1108/CG-11-2014-0140

Shen, H., Fu, M., Pan, H., Yu, Z., \& Chen, Y. (2020). The Impact of the COVID-19 Pandemic on Firm Performance. Emerging Markets Finance and Trade, 56(10), 2213-2230. https://doi.org/10.1080/1540496X.2020.178 5863

Skvortsova, T. A., Pasikova, T. A., Vereshchagina, L. N., Pozdnishov, A. N., \& Sukhovenko, A. V. (2020). The Problem of Bankruptcy of Business Entities as a Consequence of the COVID-19 Pandemic. International Journal of Economics and Business Administration, VIII(Issue 4 428-837. https://doi.org/10.35808/ijeba/632

Susilowati, E., \& Simangunsong, J. M. (2019). Financial Distress, Bankruptcy Analysis and Implications For Stock Prices of Consumer Goods Companies in Indonesia. RELEVANCE: Journal of Management and Business, 2(2), 227-240. https://doi.org/10.22515/relevance.v2i2.186 2

Usheva, M., \& Vagner, L. (2020). Earnings Management as a Tool of Bankruptcy Prevention during Global Pandemic of COVID-19. SHS Web of Conferences Globalization and Its Socio-Economic Consequences, $\quad 92$, 02063. https://doi.org/10.1051/shsconf/202192020 63

Wang, J., Yang, J., Iverson, B. C., \& Kluender, R. (2020). Bankruptcy and the COVID-19 Crisis. Harvard Business School Working Paper 21-041. https://doi.org/10.2139/ssrn.3690398

Wulandari, E. Y., \& Maslichah. (2021). 
AFRE Accounting and Financial Review Vol. 3 (2) 2020: 165-171

Penggunaan Model Springate, Ohlson, Altman Z-Score, dan Grover Score Untuk Memprediksi Financial Distress pada Masa Pandemi COVID-19 (Studi pada Perusahaan Manufaktur yang Terdaftar di Bursa Efek Indonesia). E-Jra, 10(05), 90-103. http://riset.unisma.ac.id/index.php/jra/art icle/view/10620

Zakariya, R., Tinggi, S., \& Indonesia, H. (2020). Pemeriksa Keuangan Pada Masa Pandemi Covid19. 